\title{
Effects of stoichiometry and temperature perturbations on beech leaf litter decomposition, enzyme activities and protein expression
}

\author{
K. M. Keiblinger ${ }^{1, *}$, T. Schneider ${ }^{2, *}$, B. Roschitzki ${ }^{3}$, E. Schmid ${ }^{2}$, L. Eberl $^{2}$, I. Hämmerle ${ }^{4}$, S. Leitner ${ }^{1,4}$, A. Richter ${ }^{4}$, \\ W. Wanek ${ }^{4}$, K. Riedel ${ }^{2,5}$, and S. Zechmeister-Boltenstern ${ }^{1}$ \\ ${ }^{1}$ BOKU - University of Natural Resources and Life Sciences, Institute of Soil Research, Department of Forest- and Soil \\ Sciences, Peter-Jordan Strasse 82, 1190 Vienna, Austria \\ ${ }^{2}$ University of Zurich, Institute of Plant Biology, Winterthurerstrasse 190, 8057 Zürich, Switzerland \\ ${ }^{3}$ Functional Genomics Center, University and ETH Zurich, Winterthurerstrasse 190, 8057 Zürich, Switzerland \\ ${ }^{4}$ Department of Chemical Ecology and Ecosystem Research, University of Vienna, Althanstraße 14, 1090 Vienna, Austria \\ ${ }^{5}$ Institute of Microbiology, University Greifswald, Friedrich-Ludwig-Jahn-Strasse 15, 17487 Greifswald, Germany \\ *These authors contributed equally to this work.
}

Correspondence to: K. M. Keiblinger (katharina.keiblinger@boku.ac.at)

Received: 4 November 2011 - Published in Biogeosciences Discuss.: 12 December 2011

Revised: 24 October 2012 - Accepted: 25 October 2012 - Published: 16 November 2012

\begin{abstract}
Microbes are major players in leaf litter decomposition and therefore advances in the understanding of their control on element cycling are of paramount importance. Our aim was to investigate the influence of leaf litter stoichiometry in terms of carbon $(\mathrm{C})$ : nitrogen $(\mathrm{N})$ : phosphorus $(\mathrm{P})$ ratios on the decomposition processes and to track changes in microbial community structures and functions in response to temperature stress treatments. To elucidate how the stoichiometry of beech leaf litter (Fagus sylvatica L.) and stress treatments interactively affect the microbial decomposition processes, a terrestrial microcosm experiment was conducted. Beech litter from different Austrian sites covering $\mathrm{C}: \mathrm{N}$ ratios from 39 to 61 and $\mathrm{C}: \mathrm{P}$ ratios from 666 to 1729 were incubated at $15^{\circ} \mathrm{C}$ and $60 \%$ moisture for six months. Part of the microcosms were then subjected to severe changes in temperature $\left(+30{ }^{\circ} \mathrm{C}\right.$ and $\left.-15^{\circ} \mathrm{C}\right)$ to monitor the influence of temperature stress. Extracellular enzyme activities were assayed and respiratory activities measured. A semiquantitative metaproteomics approach (1D-SDS PAGE combined with liquid chromatography and tandem mass spectrometry; unique spectral counting) was employed to investigate the impact of the applied stress treatments in dependency of litter stoichiometry on structure and function of the decomposing community. In litter with narrow $\mathrm{C}$ : nutrient $(\mathrm{C}: \mathrm{N}, \mathrm{C}: \mathrm{P})$ ratios, microbial decomposers were most abundant. Cellulase, chitinase, phosphatase and protease activity
\end{abstract}

decreased after heat and freezing treatments. Decomposer communities and specific functions varied with site, i.e. stoichiometry. The applied stress combined with the respective time of sampling evoked changes of enzyme activities and litter $\mathrm{pH}$. Freezing treatments resulted in a decline in residual plant litter material and increased fungal abundance, indicating slightly accelerated decomposition. Overall, a strong effect of litter stoichiometry on microbial community structures and functions was detected, but decomposition was mainly driven by a combination of the investigated factors. Temperature perturbations resulted in short- to medium-term alterations of microbial functions; especially high temperature treatments blocked decomposing enzymes.

\section{Introduction}

By decomposing natural compounds, microbes exert a major control on global biogeochemical cycles, thereby affecting climate and nutrient availability in the biosphere. This is reflected by a large increase in litter decomposition investigations over the last decades (Prescott, 2010). Litter decomposition rates are strongly affected by litter quality and are limited by certain threshold values for lignin: $\mathrm{N}$ ratios, polyphenols, phosphorus, organisms and abiotic factors like temperature, precipitation and soil moisture (Prescott, 2010; Luo 
et al., 2008; Couteaux et al., 1995). The biological degradation of litter is mainly carried out by decomposers, including microbes (bacteria and fungi) which have lower $\mathrm{C}$ : nutrient values compared to the substrate they consume, i.e. litter. There are different stoichiometric $(\mathrm{C}: \mathrm{N}: \mathrm{P})$ demands and constraints on the decomposition processes, based on microbial group and life strategies (Keiblinger et al., 2010). In terms of $\mathrm{C}$ cycling processes, bacteria and fungi are major players due to their inherent stoichiometry of $\mathrm{C}$ and $\mathrm{N}$. While bacteria are dominating in aquatic ecosystems, this is different for terrestrial ecosystems where fungi play an important role in nutrient cycling processes (de Boer et al., 2005). Fungi have the ability to degrade highly recalcitrant compounds by excreting extracellular enzymes and seem to dominate the production of a wide range of extracellular enzymes that break down complex high molecular organic matter (Romani et al., 2006; de Boer et al., 2005) in order to make these substrates available for microbial nutrition. Therefore, the microbial community is thought to greatly benefit from the presence of fungi as important providers of assimilable substrates and nutrients to the whole microbial community (Romani et al., 2006; de Boer et al., 2005).

Nutrient demands of microbes and extracellular enzyme activities are linked with available substrate and biomass production by their elemental stoichiometry (i.e. the $\mathrm{C}: \mathrm{N}$ : P ratio; Sinsabaugh et al., 2008). In addition, they are involved in mineralization of $\mathrm{P}$, humus formation, the degradation of microbial cell walls and plant material, and are therefore of major importance during leaf litter decomposition (Allison et al., 2006). Enzyme activities provide information about the biogeochemical and microbiological situation in an ecosystem, i.e. nutrient limitation, microbial activity, perturbation responses and organic matter characteristics (Allison et al., 2006).

Numerous environmental factors may affect microbial community activity and structure (Nannipieri et al., 2003). Under steady state environmental conditions, it is proposed that a minimum number of species is necessary for ecosystem functioning, but during and after perturbations a larger number of species are essential to maintain stable process rates (Nannipieri et al., 2003). An increase of the Earth's surface temperature by $1.5-6.4 \mathrm{~K}$ by the end of the 21 st century is forecasted by the IPCC (2007), and perturbations are thought to become more frequently, whereas the intensity of extreme weather events such as heat-waves are thought to increase considerably in the forthcoming decades (Christensen and Christensen, 2007; Fischer and Schar, 2010). With climate change, it is expected that $\mathrm{C}: \mathrm{N}$ ratios will increase by increased atmospheric $\mathrm{CO}_{2}$. When substrate $\mathrm{C}: \mathrm{N}$ is high, decomposing microorganisms need more $\mathrm{N}$, whereas $\mathrm{N}$ mineralization, the main source of $\mathrm{N}$ for plants (Hungate et al., 2003), can be reduced. Nitrogen enters the terrestrial biosphere through biological fixation and atmospheric deposition, which is an anthropogenic impact (Hungate et al., 2003). For litter decay rates, it is expected that these impacts change either the $\mathrm{C}: \mathrm{N}$ ratio or the lignin fraction in leaves (Carreiro et al., 2000). In addition, decomposition rates are strongly related to the activities of cellulose and lignin degrading enzymes, but the relationship between enzyme concentrations and substrate degradation remains poorly understood for most C compounds (Allison and Vitousek, 2005).

To monitor directly the functional responses of microbial communities to natural and anthropogenic changes, microbial enzyme activity analysis are useful to follow the responses of microbial breakdown and acquisition of specific $\mathrm{C}$ resources.

To examine these influences (i.e. stoichiometry, perturbations) on the microbial community in environmental samples, metaproteomics is considered to be a powerful tool as it deals with finally processed proteins active for allocation of nutrients for microbial nutrition and allows linking the structure and physiology of complex microbial consortia (Nannipieri et al., 2003; Nannipieri, 2006; Ogunseitan, 2006). Additionally, microbial enzyme activity measurements may relate leaf litter decomposition to specific extracellular enzymes acquiring $\mathrm{C}, \mathrm{N}$ and $\mathrm{P}$, as constrained by microbial biomass stoichiometry (Sinsabaugh et al., 2008). Recently, Schneider et al. (2012) demonstrated the applicability of metaproteomics to analyse the community structure and function in leaf litter samples. Relating leaf litter stoichiometry, metaproteome and enzyme activities to the effects of temperature perturbations will provide new insights into the microbial processes during leaf litter decomposition.

Our aim was to investigate changes in microbial decomposer structure and function during leaf litter decomposition as affected by leaf litter stoichiometry ( $\mathrm{C}$ : nutrient ratios) and temperature perturbations (heat and freezing stress) in a system under harsh stress conditions. In this microcosm experiment, beech litter (Fagus sylvatica L.) from three different sites was used in order to ensure similar litter biochemistry (i.e. lignin content) and answer the following questions:

$Q 1$ : Which factors - resource stoichiometry, temperature treatments or sampling time - have the strongest effects on microbial community structure and function?

$Q 2:$ How do extreme temperatures affect microbial function (enzyme activities)?

Q3: Is it possible to link microbial community structure using metaproteomics to its decomposer function and the contribution of major phylogenetic groups to the decomposition process?

\section{Material and methods}

\subsection{Experimental setup}

Beech (Fagus sylvatica L., 1753) litter with different elemental and stoichiometric composition $(\mathrm{C}: \mathrm{N}: \mathrm{P})$ (Table 1) was collected at three sites across Austria in autumn 2008 
Table 1. Stoichiometry $-\mathrm{C}: \mathrm{N}$ ratios and $\mathrm{C}: \mathrm{P}$ ratios of the litter types from the respective locations at the different treatments and sampling time points, including the initial time point zero (baseline).

\begin{tabular}{|c|c|c|c|c|c|c|c|c|c|c|}
\hline & & \multicolumn{3}{|c|}{ Klausenleopoldsdorf } & \multicolumn{3}{|c|}{ Ossiach } & \multicolumn{3}{|c|}{ Schottenwald } \\
\hline & & control & frost & heat & control & frost & heat & control & frost & heat \\
\hline \multirow{3}{*}{$\mathrm{C}: \mathrm{N}$} & initial sampling & $51.2 \pm 0.82$ & & & $61.8 \pm 1.8$ & & & $41.7 \pm 0.71$ & & \\
\hline & 1st sampling & $49.8 \pm 1.74$ & $50.2 \pm 1.97$ & $51.9 \pm 3.33$ & $60.7 \pm 0.89$ & $60.9 \pm 0.71$ & $61.2 \pm 0.92$ & $40.3 \pm 0.58$ & $41.3 \pm 1.65$ & $41.0 \pm 2.18$ \\
\hline & 2nd sampling & $50.9 \pm 0.46$ & $48.9 \pm 1.47$ & $48.3 \pm 0.98$ & $57.7 \pm 2.54$ & $57.6 \pm 2.79$ & $58.1 \pm 2.13$ & $39.7 \pm 3.37$ & $39.1 \pm 1.52$ & $38.9 \pm 1.09$ \\
\hline \multirow{3}{*}{$\mathrm{C}: \mathrm{P}$} & initial sampling & $1510 \pm 46$ & & & $902 \pm 39$ & & & $684.4 \pm 26$ & & \\
\hline & 1st sampling & $1486 \pm 47$ & $1389 \pm 69$ & $1372 \pm 274$ & $914 \pm 41$ & $900 \pm 41$ & $850 \pm 34$ & $695 \pm 25$ & $672 \pm 24$ & $666 \pm 57$ \\
\hline & 2nd sampling & $1729 \pm 63$ & $1551 \pm 82$ & $1551 \pm 30$ & $921 \pm 48$ & $933 \pm 38$ & $850 \pm 19$ & $713 \pm 34$ & $676 \pm 35$ & $692 \pm 17$ \\
\hline
\end{tabular}

(Wanek et al., 2011): Klausenleopoldsdorf (KL) (Kitzler et al., 2006), Ossiach (OS) and Schottenwald (SW). The collected litter was dried at $40^{\circ} \mathrm{C}$ for $48 \mathrm{~h}$, shred into pieces and sieved $(<1 \mathrm{~cm})$. A fraction of pieces between $2 \mathrm{~mm}$ and $1 \mathrm{~cm}$ size was sterilized by $\gamma$-radiation (Wanek et al., 2011). The litter was inoculated with a suspension of an Ohorizon : litter mixture $(1: 1, w: w)$ collected from Klausenleopoldsdorf in December 2008 to obtain an identical initial microbial community structure on all three litter types (Leitner et al., 2012). After thoroughly mixing of the litter with inoculum suspension amounting to $1.5 \%$ dry weight of litter (Leitner et al., 2012), microcosms, which had been prepared from PVC plastic tubing $(10 \mathrm{~cm}$ length, $12.5 \mathrm{~cm}$ diameter, bottom lid perforated plastic grid) (Wanek et al., 2011), were filled with $60 \mathrm{~g}$ of litter fresh weight for all three litter types (KL, OS and SW). Five replicates of all treatments, controls and sampling time points (see below) were prepared, giving 90 microcosms in total. The microcosms were laced in trays lined with wet cloth and were capped with lids of micromesh cloth to ensure $\mathrm{CO}_{2}$ exchange during incubation (Mooshammer et al., 2011). For respiration measurements, microcosms were closed with airtight rubber on the bottom and a reduction gadget on the top for use with a SRC-1 chamber system (see below: PPSystems, USA). Microcosms were initially incubated at $15^{\circ} \mathrm{C}$ for 25 weeks. After 12 weeks, treatments were performed as follows: the microcosms were either heat treated $\left(3\right.$ days at $23^{\circ} \mathrm{C}, 5$ days at $30^{\circ} \mathrm{C}, 1$ day at $23^{\circ} \mathrm{C}$ and 3 days before sampling back to $15^{\circ} \mathrm{C}$ ) or freezing treated ( 3 days at $4{ }^{\circ} \mathrm{C}, 5$ days at $-15^{\circ} \mathrm{C}, 1$ day at $4{ }^{\circ} \mathrm{C}$ and 3 days before sampling back to ambient temperature). Two weeks after beginning the treatments, the first sampling was performed, with a second sampling three months later. Water content of the litter was maintained at $60 \%$ fresh-weight by adding autoclaved tap water weekly. Litter samples were analysed in five replicated microcosms for each treatment (control, heat, and freezing).

\subsection{Litter moisture and nutrient concentrations}

Litter moisture was determined gravimetrically on an aliquot of litter (by drying at $65^{\circ} \mathrm{C}$ ). Dry samples were ground to a fine powder. The total $\mathrm{C}$ and $\mathrm{N}$ contents of the litter samples were analysed with an elemental analyser (Leco CN2000, LECO Corp. St Joseph, MI, USA). Further, the ground samples were wet oxidized with an acid mixture $\left(\mathrm{H}_{2} \mathrm{SO}_{4}\right.$ and $\left.\mathrm{HNO}_{3}\right)($ Henschler, 1988) in a microwave oven and elemental concentrations $(\mathrm{P}, \mathrm{K}, \mathrm{Mg}, \mathrm{Mn}, \mathrm{Ca}, \mathrm{Fe})$ determined by inductively coupled plasma atomic emission spectrometry (ICP-AES). Litter $\mathrm{C}: \mathrm{N}$ and $\mathrm{C}: \mathrm{P}$ ratios are given in Table 1.

\subsection{Microbial biomass carbon $\left(\mathrm{C}_{\text {mic }}\right)$, nitrogen $\left(\mathrm{N}_{\text {mic }}\right)$ and phosphorus $\left(\mathbf{P}_{\text {mic }}\right)$}

Litter samples were analyzed for microbial biomass $\mathrm{C}$ and microbial biomass $\mathrm{N}$ and $\mathrm{P}$ contents using the chloroform fumigation-extraction method as described by Schinner et al. (1996). Control samples were not fumigated but extracted in the same way as fumigated ones. Samples were extracted in a ratio of $1: 33(w: v)$ with $0.5 \mathrm{M} \mathrm{K}_{2} \mathrm{SO}_{4}$-solution. The total amount of dissolved $\mathrm{C}$ and $\mathrm{N}$ was determined with a TOC-V CPH E200V, linked with a TN-unit TNM1 (Shimadzu Corporation, Kyoto, Japan). The total amount of microbial $\mathrm{P}$ was determined with a persulfate digestion of the $0.5 \mathrm{M} \mathrm{K}_{2} \mathrm{SO}_{4}$ extracts based on Doyle et al. (2004). Phosphate was quantified photometrically at a wavelength of $882 \mathrm{~nm}$ based on the phosphomolybdate blue reaction (Schinner et al., 1996) with a Microplate Reader (BIOTEK Instruments, Inc.). The $0.5 \mathrm{M} \mathrm{K}_{2} \mathrm{SO}_{4}$ extracts were kept frozen $\left(-20^{\circ} \mathrm{C}\right)$ until analysis.

\subsection{Respiration measurements}

Respiration of the litter within the microcosms was monitored once a week using an infrared gas analyzer (IRGA, EGM4 with SRC1, PPSystems, USA). Measurements were conducted using the following settings: volume of the chamber $1551 \mathrm{~cm}^{3}$, area of the chamber $115 \mathrm{~cm}^{2}$, linear data fit to measured increase in $\mathrm{CO}_{2}$, and respective temperature within the incubation chamber. $\mathrm{CO}_{2}$ concentrations were measured over $70 \mathrm{~s}$ and the increase in $\mathrm{CO}_{2}$ concentration per second was calculated based on gram litter dry weight. Measurements of ambient air were performed before and after each measurement to assess possible leaks or base-line drifts of the IRGA system (EGM4 with SRC1). Accumulated 
respiration was calculated assuming linear transition between weekly measurements.

\subsection{Enzyme activities}

Potential extracellular enzyme activities were measured using microplate fluorometric and photometric assays. All activities were measured within $48 \mathrm{~h}$ of litter sampling.

\subsubsection{Cellulase, chitinase, phosphatase and protease}

Extracellular $\beta$-1,4-cellobiosidase ("cellulase"), $\beta-1,4-\mathrm{N}$ acetylglucosaminidase, chitinase/lysozyme ("chitinase") and leucine amino-peptidase ("protease") were measured fluorimetrically (Kaiser et al., 2010). In short, $200 \mu \mathrm{l}$ of litter suspension were pipetted in microplates and $50 \mu \mathrm{l}$ substrate were added. The substrate used for measuring cellulose activity was 4 -methylumbelliferyl- $\beta$-d-cellobioside (MUFcellobioside). For chitinase activity, two different substrates were used, MUF-N-acetyl- $\beta$-d-glucosaminide and MUF- $\beta$ $\mathrm{d}-\mathrm{N}, \mathrm{N}^{\prime}, \mathrm{N}^{\prime \prime}$-triacetylchitotrioside, to cope with the possibility of steric hindrance for polymer degradation. For phosphatase, MUF-P served as substrate. Activity was measured by following the release of 4-methylumbelliferone (MUF) from the respective substrate (cellulase, chitinases and phosphatase). For the protease assay, L-leucine-7-amido4-methyl coumarin (AMC) was used as substrate, and the released coumarin adduct was measured with fluorescence. For calibration, methylumbelliferyl (MUF) was used for cellulose, chitinase and phosphatase activity, whereas AMC was used for calibration of protease activity. Plates were incubated for $140 \mathrm{~min}$ in the dark and fluorescence was measured at $450 \mathrm{~nm}$ emission wavelength and at an excitation wavelength of $365 \mathrm{~nm}$ using a Tecan Infinite M200 Fluorimeter (Werfen, Austria).

\subsubsection{Phenoloxidase, peroxidase}

Phenoloxidase and peroxidase activities were measured photometrically based on standard methods (Kaiser et al., 2010), using L-3,4-dihydroxyphenylalanin (L-DOPA, Sigma- Aldrich, Vienna, Austria) in microplates. Litter suspension was mixed with a $20 \mathrm{mM}$ L-DOPA solution $(1: 1)$. After shaking the samples for $10 \mathrm{~min}$, they were centrifuged and pipetted into microplates. For peroxidase measurement wells additionally received $10 \mu \mathrm{l}$ of a $0.3 \% \mathrm{H}_{2} \mathrm{O}_{2}$ solution. At the beginning and after $20 \mathrm{~h}$, absorption was measured at $450 \mathrm{~nm}$. Enzyme activity was calculated from the increase in absorption over time divided by the molar extinction coefficient.

\subsection{Metaproteome analysis}

From the five replicates of each treatment and harvest, samples were stored at $-80^{\circ} \mathrm{C}$, whereas litter material from one replicate was analysed by metaproteomics, resulting in a to- tal of 18 samples. This was the upper limit of what could be achieved in this project as one metaproteomic sample takes at least five days of processing and analysis. Aliquots $(3 \mathrm{~g})$ of litter material were ground in liquid nitrogen and the resulting powder was mixed with extraction buffer containing $1 \%$ SDS, $50 \mathrm{mM}$ Tris/KOH, $\mathrm{pH} 7.0$ in a $1: 5$ ratio $(w / v)$. Samples were sonicated for $2 \mathrm{~min}$ followed by boiling for $20 \mathrm{~min}$ and shaking at $4{ }^{\circ} \mathrm{C}$ for $1 \mathrm{~h}$. To remove debris, extracts were centrifuged at $3000 \mathrm{~g}$ at $4{ }^{\circ} \mathrm{C}$ for $10 \mathrm{~min}$. Supernatants were removed and centrifuged for $5 \mathrm{~min}$ at $14000 \mathrm{~g}$ and $4{ }^{\circ} \mathrm{C}$. Supernatants were concentrated about 5-fold by vacuum-centrifugation (Eppendorf Vacuum Concentrator plus) at $30^{\circ} \mathrm{C}$. Then $25 \mu \mathrm{l}$ of concentrated supernatants were subjected to 1D-SDS-PAGE (Laemmli, 1970) in a $12 \%$ polyacrylamide gel to clean samples from interfering substances (e.g. humic acids) and to reduce sample complexity. Protein lanes were cut into four slices and the gel slices subjected to in-gel tryptic digestion by employing sequencing grade modified trypsin (Promega, reference V5111) (Shevchenko et al., 1996). The resulting peptide mixtures were analysed on a hybrid LTQ-Orbitrap mass spectrometer (ThermoFisher Scientific) interfaced with a nanoelectrospray ion source. Chromatographic separation of peptides was achieved on an Eksigent nano LC system (Eksigent Technologies, Dublin, CA, USA) equipped with an $11 \mathrm{~cm}$ fused silica emitter, $75 \mu \mathrm{m}$ inner diameter (BGB Analytik, Böckten, Switzerland), packed inhouse with a Magic C18 AQ $3 \mu \mathrm{m}$ resin (Michrom BioResources, Auburn, CA, USA). Peptides were loaded from a cooled $\left(4^{\circ} \mathrm{C}\right)$ Spark Holland auto sampler and separated using an acetonitrile/water solvent system containing $0.1 \%$ formic acid at a flow rate of $200 \mathrm{nl} \mathrm{min}^{-1}$ with a linear gradient from 3 to $35 \%$ acetonitrile in $60 \mathrm{~min}$. Up to 6 data-dependent MS/MS spectra were acquired in the linear ion trap for each Fourier-transform (FT)-MS spectral acquisition range. The latter was acquired at 60000 full-width half-maximum (FWHM) nominal resolution settings with an overall cycle time of approximately 1 second. Charge state screening was employed to select for ions with two charges and rejecting ions in single-charge state. The automatic gain control (AGC) was set at $5 \mathrm{e}^{5}$ for ion injection control and at $1 \mathrm{e}^{4}$ for full FT-MS and linear ion trap MS/MS. The instrument was calibrated externally according to the manufacturer's instructions. All samples were acquired using internal lock mass calibration on $m / z 429088735$ and 445120025 .

\subsection{Database searches}

The MASCOT search engine (version no. 2.2.04) was used for protein database searches. MS and MS/MS data were searched against a database containing all proteins from UniRef100 (9808438 entries, downloaded from the European Bioinformatics Institute webpage http://www.ebi.ac.uk/ uniref/ (last access: 26 January 2010) and protein sequence information from a translated metagenome of the microbial 
community of a Minnesota farm silage soil (Tringe et al., 2005; 184374 entries, downloaded from http://img.jgi.doe. gov (last access: 15 October 2009) as well as common contaminants like keratin and trypsin (total no. of entries 9993 117). The following search parameters were applied: (i) trypsin was chosen as protein-digesting enzyme and up to two missed cleavages were tolerated, (ii) carbamidomethylation of cystein was chosen as fixed modification, and (iii) oxidation of methionine was chosen as variable modification. Searches were performed with a parent-ion mass tolerance of $\pm 5 \mathrm{ppm}$ and a fragment-ion mass tolerance of $\pm 0.8 \mathrm{Da}$. A second database search was performed with the $\mathrm{X}$ !Tandem (version 2007.01.01.1) search engine (Craig and Beavis, 2004) with similar settings.

\subsection{Data processing}

Scaffold (version Scaffold 3.0, Proteome Software, Portland, OR, USA) was used to validate and quantify MS/MS based peptide and protein identifications from both search engines. Peptide identifications were accepted if they were established at greater than $99 \%$ probability, as specified by the Peptide Prophet algorithm (Keller et al., 2002). Protein identifications were accepted if they were established at greater than $90 \%$ probability and at least one peptide was uniquely assigned to a respective protein in one of our samples. Protein probability was assigned by the Protein Prophet algorithm (Nesvizhskii et al., 2003). Proteins that were identified with the same set of peptides and could not be differentiated by the MS/MS analysis were grouped to protein clusters to satisfy the principles of parsimony. A protein false discovery rate of $5.5 \%$ was calculated by the Scaffold software.

\subsection{Data validation and quantitative assignment of data to phylogenetic and functional groups}

Starting from the Scaffold output files, all protein hits obtained by the database searches were assigned to phylogenetic and functional groups and assignments were validated by a newly developed perl-script based PROteomics result Pruning \& Homology group ANotation Engine (PROPHANE) (Schneider et al., 2011) workflow (http://prophane. svn.sourceforge.net/viewvc/prophane/trunk/). To this end, protein clusters were checked for sequence homology at a $50 \%$ identity threshold. Afterwards, phylogenetic information of each protein hit was retrieved from the Swissprot database. If Swissprot was not available, the Entrez database was used instead. For functional assignments, proteins were blasted against the KEGG database, the cluster of orthologous group (COG) database and Swissprot. If a protein cluster contained more than one protein hit, clusters were checked for consistency in the phylogenetic and functional assignments (Schneider et al., 2011). Finally, protein abundances were calculated based on the normalized spectral abundance factor (Zybailov et al., 2006; Florens et al., 2006).
In this process, the numbers of unique spectra assigned to each protein are divided by the number of the amino acid chain length of the longest candidate in the protein cluster, giving the spectral abundance factor (SAF). The SAF allows the comparison of protein abundances in one sample with taking into account protein molecular weight. Afterwards each SAF is divided by the sum of all SAFs in the respective sample to allow cross-sample abundance comparison.

\subsection{Data evaluation and statistical analyses}

For individual analyses of the effects of litter stoichiometry on processes and microbial community structure, we performed simple linear regression (SLR) analysis. For SLR, we tested the residues to check if the assumption of normal distribution was met by using the Shapiro-Wilk test. When the assumption of normal distribution was violated, the data were $\log$ transformed to approach normal distribution. Individual tests between the parameters sampling time were evaluated using Student's t-test. To evaluate differences between multiple groups (i.e. treatment), we used one-way analysis of variance (ANOVA) and post-hoc Tukey HSD, respectively. To evaluate which factor (litter type-"site", "time", "treatment") best predicted differences in decomposition, we performed a principal component analysis (PCA). To evaluate the influence of treatment, site and time and their combination on microbial functions, we performed a multivariate ANOVA (MANOVA). All statistical analyses were conducted using SAS Enterprise 4 (SAS Institute, 1992) or PASW 18.0 (SPSS) statistical software packages.

\section{Results}

The presented experiment was designed to evaluate the impact of different factors on decomposition of beech litter. The factors were the different "treatments" ("treat") of the microcosms (heat and freezing), the litter types from three locations as the factor "site", which differed in nutrient stoichiometry, and sampling "time points" ( 2 weeks and 3 months after treatment). To evaluate our research questions and which of the above mentioned factors had the most pronounced effects on beech litter decomposition, a multivariate analysis of variance (MANOVA) was conducted. Potential extracellular enzyme activities were investigated in detail, as they are a measure of microbial community function and they play an important role in litter decomposition. MANOVA revealed that the interaction of all three factors "site-time-treat" significantly predicted chitinase activity (Table 2). Only two measures, phosphatase and respiration $\left(\mathrm{CO}_{2}\right)$, did not show significant results for an interaction term. Each factor itself was highly significant $(p<0.0001)$ for phosphatase activity, with the highest F-value observed for treatment, which therefore seemed to be most predictive for phosphatase. This effect surrogates that there was 
Table 2. Multivariate ANOVA with the factors "site", "treat" (treatment) and "time" (sampling time) and their interaction terms, to evaluate their impact on different parameters like cellulase, chitinase, phosphatase, protease, peroxidase and phenoloxidase activity and respiration activity $\left(\mathrm{CO}_{2}\right)$.

\begin{tabular}{|c|c|c|c|c|c|c|c|c|c|c|c|c|c|c|}
\hline & \multicolumn{2}{|c|}{ site } & \multicolumn{2}{|c|}{ treat } & \multicolumn{2}{|c|}{ site-treat } & \multicolumn{2}{|c|}{ time } & \multicolumn{2}{|c|}{ time-site } & \multicolumn{2}{|c|}{ time-treat } & \multicolumn{2}{|c|}{ time-site-treat } \\
\hline & $F$ & $p$ & $F$ & $p$ & $F$ & $p$ & $F$ & $p$ & $F$ & $p$ & $F$ & $p$ & $F$ & $p$ \\
\hline Cellulase & 89.7 & $<.0001$ & 121.4 & $<.0001$ & 2.7 & 0.0459 & 30.8 & $<.0001$ & 4.7 & 0.0149 & 57.6 & $<.0001$ & 1.9 & 0.1341 \\
\hline Chitinase & 142.7 & $<.0001$ & 329.2 & $<.0001$ & 21.1 & $<.0001$ & 14.6 & 0.0005 & 3.1 & 0.0575 & 89.6 & $<.0001$ & 5.5 & 0.0015 \\
\hline Phosphatase & 18.3 & $<.0001$ & 1237.5 & $<.0001$ & 2.0 & 0.1142 & 33.2 & $<.0001$ & 1.7 & 0.2057 & 0.1 & 0.9229 & 2.3 & 0.0758 \\
\hline Protease & 10.7 & 0.0002 & 21.5 & $<.0001$ & 1.9 & 0.128 & 1.5 & 0.226 & 15.9 & $<.0001$ & 31.0 & $<.0001$ & 2.3 & 0.0789 \\
\hline Peroxidase & 61.1 & $<.0001$ & 8.9 & 0.0007 & 4.8 & 0.0034 & 74.1 & $<.0001$ & 19.0 & $<.0001$ & 5.4 & 0.0092 & 1.3 & 0.2887 \\
\hline Phenoloxidase & 98.8 & $<.0001$ & 27.7 & $<.0001$ & 2.0 & 0.1107 & 5.3 & 0.0271 & 12.0 & 0.0001 & 4.2 & 0.0233 & 2.1 & 0.0977 \\
\hline $\mathrm{CO}_{2}$ & 6.3 & 0.0049 & 1.6 & 0.2268 & 2.6 & 0.0572 & 0.6 & 0.4588 & 0.1 & 0.91 & 1.3 & 0.2801 & 1.6 & 0.1977 \\
\hline
\end{tabular}

no P-limitation, otherwise the factor "site" would have been more pronounced. Respiration was predicted only by "site". All other parameters had significant interaction for at least one of the interaction terms with two factors. While for cellulase activity and protease activity the interaction term "timetreat" showed highly significant results, peroxidase and phenoloxidase were highly significant when combining the factors "time" and "site". As phenoloxidase and peroxidase are enzymes specialized in the degradation of lignin, the interaction of time and site indicates a combined effect of degradercommunity succession and nutrient availability that regulates enzyme production. The observed time and treatment combination for cellulase and protease suggests that disturbance through temperature perturbations had a stronger impact than the nutritional situation. Nevertheless, enzyme activities were all significant for each single factor except for protease activity and the factor "time".

The MANOVA showed strong influences of the factors "time-site" (besides "time-site-treat"), which indicates that all factors had a major function in defining the response of the microbial community to the applied experimental conditions.

As shown in Fig. 1, there was a significant decline in cellulase, chitinase and phosphatase activity after heat or freezing treatments in comparison to controls. Protease activity declined as well, but not significantly for both treatments at the first sampling time point. Heat resulted in a stronger decline of enzyme activities than freezing.

In order to identify the main site/litter properties that drive microbial activity, single linear regression (SLR) was applied (Table 3) separately for each treatment. Generally, litter N concentrations were related to activities of cellulase, chitinase, phosphatase, peroxidase and phenoloxidase. Interestingly, leaf litter P concentration was not correlated with phosphatase activity, but positively related to all other enzyme activities under stable conditions (control treatment). Cellulase activity was more strongly significantly related to leaf litter nutrients $(\mathrm{N}$ and $\mathrm{P})$ after application of treatments compared to controls, especially a strong relationship with leaf litter $\mathrm{N}$ content after heat stress. Protease showed no significant re- lationship with leaf litter nutrients after freezing (Table 3), although in heat and control treatments protease was weakly related to litter $\mathrm{P}$ content. After freezing treatment, peroxidase activity decreased, although it was still significantly related to leaf litter $\mathrm{N}$ and $\mathrm{P}$ (Fig. 1; Table 3). Activities of $\mathrm{C}$-acquiring enzymes, e.g. cellulases, peroxidases and phenoloxidases, correlated positively with $\mathrm{C}_{\mathrm{mic}}$ for the control treatment. In addition, $\mathrm{N}_{\text {mic }}$ correlated positively with peroxidase and phenoloxidase activity, two enzymes which release $\mathrm{N}$ that is bound in plant cell walls due to their ligninolytic action, but this correlation did not persist for peroxidase after heat treatment. Interestingly, there was no correlation of $\mathrm{N}_{\text {mic }}$ with chitinase under equilibrium temperature conditions but a strong linear regression to $\mathrm{N}_{\text {mic }}$ after heat and freezing perturbations, and similar but only moderate linear regression for $\mathrm{P}_{\text {mic }}$ (Table 3 ). Respiration was significantly related to leaf litter $\mathrm{C}$ and $\mathrm{N}$ for controls, but after temperature perturbation, significant linear regression was observed for leaf litter $\mathrm{P}$ and $\mathrm{CO}_{2}$. Although total mass of the system did not result in significant mass losses after six months, accumulated respiration was greater in treated leaf litter compared to control samples, especially after freezing at the second sampling.

To evaluate how the microbial community is influenced by the investigated factors, its structure and function was investigated by a metaproteomics approach. In total, 1020 protein clusters were identified from which 138 were excluded from further analysis because of a lack of sequence homology in the respective clusters. The remaining 882 clusters were assigned to phylogenetic and functional groups using PROPHANE. The normalized numbers of unique spectra act as marker for the abundance of the respective groups. Cluster identification parameters as well as quantitative information and functional assignments are provided in Supplement Table S1. The complete MASCOT results data set including MS/MS spectra information is provided as online material at the PRIDE database (Vizcaino et al., 2009), at http: //www.ebi.ac.uk/pride/; accession number is 19501. In all samples, community structures were dominated by remaining plant proteins (designated as "Viridiplantae") followed 

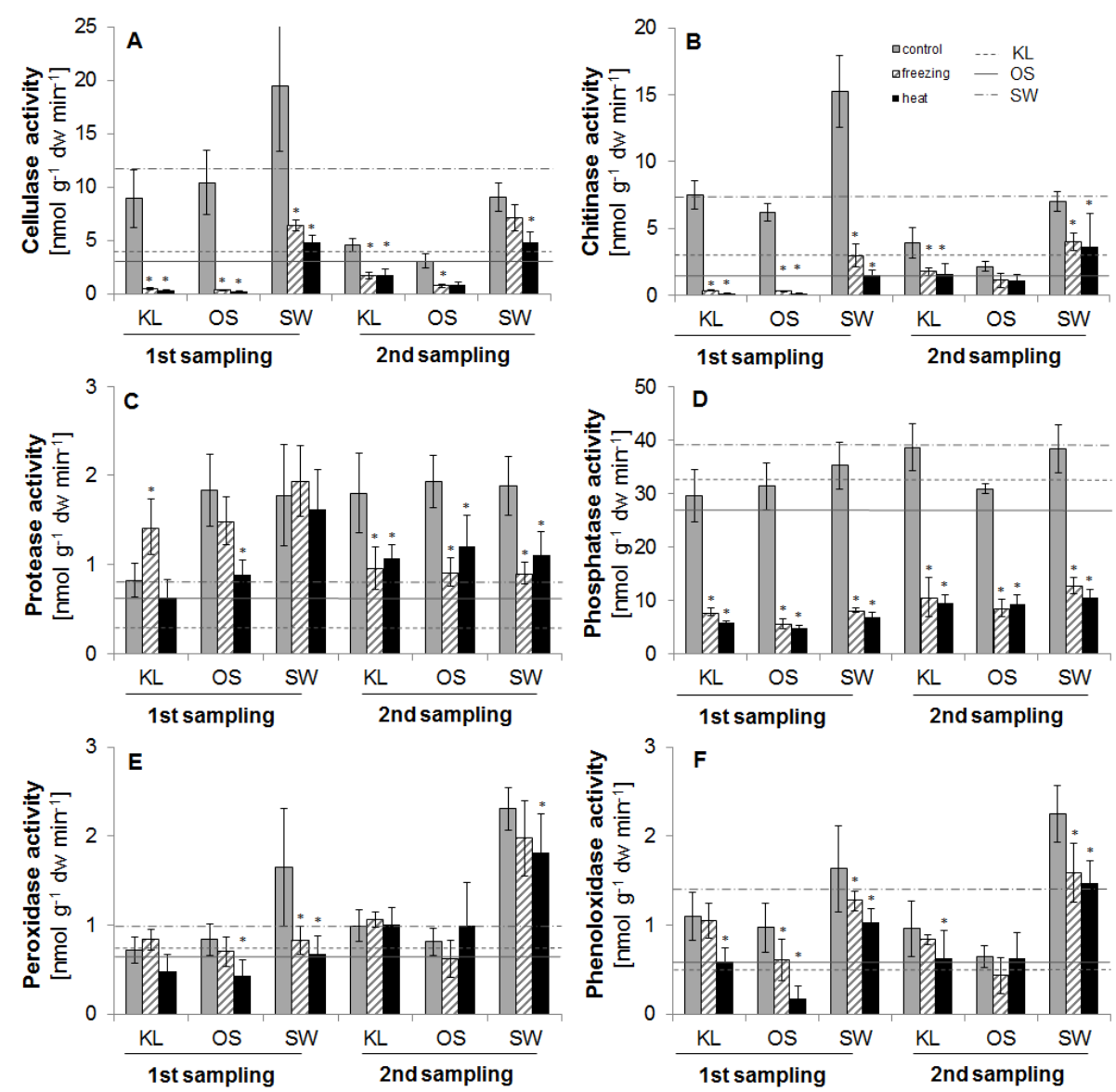

Fig. 1. Enzyme activities (A) cellulase activity, $(\mathbf{B})$ chitinase activity, $(\mathbf{C})$ protease activity, $(\mathbf{D})$ phosphatase activity, $(\mathbf{E})$ peroxidase activity and (F) phenoloxidase activity at different sampling times, treatments and sites. The different locations where the litter derived from were indicated as follows: Klausenleopoldsdorf (KL), Ossiach (OS) and Schottenwald (SW) and treatments are indicated as "control", "freezing" and "heat". Error bars indicate standard deviation. 1st sampling was two weeks after treatments and 2nd sampling was three months after treatments. Respective enzyme activities at time zero are shown as horizontal lines which are dashed for KL, solid for OS and dotted and dashed for SW. Stars indicate a significant difference $(p<0.05)$ of the treatment to control at the respective sampling time.

by fungi and bacteria (Fig. 3). Plant litter protein (Viridiplantae) loss, which can be used as a proxy for decomposition, was lowest at the nutrient poorest site (KL) and highest at the nutrient richest site (SW). Fungal and bacterial contribution to the total community was higher at nutrient richer sites. The fungal communities were dominated by Ascomycota (Eurotiomycetes, Sordariomycetes) and Basidiomycota (Agaricomycetes), while the bacterial communities were dominated by Proteobacteria, Actinobacteria and Firmicutes (Fig. 2). Changes in the relative composition of phylogenetic groups were observed for different "sites", i.e. litter stoichiometry, and stress treatments (Fig. 2). For example, in SW, fungal abundance decreased and litter decomposition was reduced (indicated by higher Viridiplantae abundance, non-degraded leaf proteins (Fig. 2) after temperature stress.

To test whether treatments had a significant influence on phylogeny, we grouped the sites to provide replicates for the treatments at the respective sampling time points. We ob- served that bacteria transiently decreased after freezing compared to the control at the first sampling, while there was no significant difference in bacterial abundance at the second sampling. Fungi were significantly increased after freezing compared to control and heat treatment, which again was a short term effect. The treatments did not significantly affect metazoa shortly after application but in the long term, as at the second sampling, the abundance of metazoa was significantly increased for heat and freezing (Fig. 3).

To assign community structure to leaf litter quality parameters, principal component analysis (PCA) was performed. Microbial community domains were separated by the different leaf litter "sites", as can be seen in the PCA biplots (Fig. 4). Results strongly indicate that stoichiometry is the overriding factor shaping the decomposer communities. While fungal abundance was ordinated in direction of the site Schottenwald (SW), which had most narrow C: nutrient ratios, the remaining plant material (Viridiplantae) was 
Table 3. Single linear regression (SLR), of litter C, N and P concentrations as well as microbial biomass $\mathrm{C}_{\text {mic }}, \mathrm{N}_{\text {mic }}$ and $\mathrm{P}_{\text {mic }}$ concentrations with respiration activity $\left(\mathrm{CO}_{2}\right)$ and cellulase, chitinase, phosphatase, protease, peroxidase and phenoloxidase activity. The values shown are $R^{2}$ and stars indicate the significance $\left({ }^{*} p \leq 0.05 ;{ }^{* *} p \leq 0.01 ;{ }^{* * *} p \leq 0.0001\right)$.

\begin{tabular}{llllllll}
\hline & $n=30$ & $\mathrm{~N}$ & $\mathrm{C}$ & $\mathrm{P}$ & $\mathrm{C}_{\mathrm{mic}}$ & $\mathrm{N}_{\text {mic }}$ & $\mathrm{P}_{\text {mic }}$ \\
\hline \multirow{6}{*}{ control } & $\mathrm{CO}_{2}$ & $0.39^{* *}$ & $0.30^{* *}$ & 0.03 & $0.20^{*}$ & $0.35^{* *}$ & $0.28^{* *}$ \\
& Cellulase & $0.24^{* *}$ & 0.00 & $0.25^{* *}$ & $0.31^{* *}$ & 0.00 & 0.01 \\
& Chitinase & $0.39^{* *}$ & 0.02 & $0.24^{* *}$ & $0.30^{* *}$ & 0.00 & 0.00 \\
& Phosphatase & $0.18^{*}$ & $0.20^{*}$ & 0.03 & $0.18^{*}$ & $0.20^{*}$ & 0.13 \\
& Protease & 0.00 & 0.03 & $0.15^{*}$ & 0.07 & 0.13 & $0.19^{*}$ \\
& Peroxidase & $0.58^{* * *}$ & 0.06 & $0.46^{* * *}$ & $0.76^{* * *}$ & $0.51^{* * *}$ & $0.47^{* * *}$ \\
& Phenoloxidase & $0.60^{* * *}$ & 0.09 & $0.33^{* *}$ & $0.66^{* * *}$ & $0.38^{* *}$ & $0.37^{* *}$ \\
\hline \multirow{5}{*}{ heat } & $\mathrm{CO}_{2}$ & 0.00 & 0.13 & $0.28^{*}$ & $0.16^{*}$ & 0.03 & 0.08 \\
& Cellulase & $0.78^{* * *}$ & 0.08 & $0.41^{* *}$ & $0.44^{* * *}$ & $0.82^{* * *}$ & $0.42^{* * *}$ \\
& Chitinase & $0.40^{* *}$ & 0.06 & 0.10 & 0.12 & $0.31^{* *}$ & $0.55^{* * *}$ \\
& Phosphatase & $0.19^{*}$ & 0.08 & 0.00 & 0.02 & 0.07 & 0.12 \\
& Protease & $0.14^{*}$ & 0.00 & $0.26^{*}$ & 0.13 & $0.38^{* *}$ & 0.09 \\
& Peroxidase & $0.25^{* *}$ & 0.05 & 0.04 & 0.00 & 0.09 & $0.22^{* *}$ \\
& Phenoloxidase & $0.63^{* * *}$ & 0.12 & $0.18^{*}$ & $0.16^{*}$ & $0.44^{* * *}$ & $0.31^{* *}$ \\
\hline & CO 2 & 0.12 & 0.05 & $0.38^{* *}$ & $0.30^{* *}$ & $0.21^{*}$ & $0.36^{* *}$ \\
& Cellulase & $0.81^{* * *}$ & $0.17^{*}$ & $0.63^{* * *}$ & $0.60^{* * *}$ & $0.89^{* * *}$ & $0.31^{* *}$ \\
& Chitinase & $0.72^{* * *}$ & $0.22^{* *}$ & $0.45^{* * *}$ & $0.40^{* *}$ & $0.71^{* * *}$ & $0.28^{* *}$ \\
freezing & Phosphatase & $0.40^{* *}$ & $0.15^{*}$ & 0.04 & 0.03 & $0.15^{*}$ & 0.05 \\
& Protease & 0.01 & 0.01 & 0.09 & 0.08 & 0.07 & 0.01 \\
& Peroxidase & $0.48^{* * *}$ & 0.11 & $0.15^{*}$ & $0.28^{* *}$ & $0.30^{* *}$ & $0.24^{* *}$ \\
& Phenoloxidase & $0.7^{* * *}$ & 0.1 & $0.30^{* *}$ & $0.52^{* * *}$ & $0.59^{* * *}$ & $0.19^{* *}$ \\
\hline
\end{tabular}

grouped to the site Klausenleopoldsdorf (KL) (wide C:P). Viridiplantae abundance was directed opposite to $\mathrm{P}$ and $\mathrm{P}_{\mathrm{mic}}$ (Fig. 4). Bacteria and Metazoa were grouped to the site Ossiach (OS), opposite to leaf litter $\mathrm{C}$ concentration. Fungal abundance was closely related to leaf litter nutrients $(\mathrm{N}, \mathrm{P})$ and stoichiometry $(\mathrm{C}: \mathrm{N}, \mathrm{C}: \mathrm{P})$, as evident in the PCA analysis (Fig. 4a).

Principal component analysis of the microbial community at the phylum level (Fig. 4b) indicated that Proteobacteria and Basidiomycota delineated towards OS with a negative relation to litter $\mathrm{C}$ concentration. The class of $\gamma$-Proteobacteria was ordinated close to the site OS (Fig. 4c) and opposite to litter C. The fungal classes of Dothideomycetes, Eurotiomycetes and Sordariomycetes were grouped to SW (Fig. 4d), and correlated negatively with $\mathrm{C}: \mathrm{N}$ and $\mathrm{C}: \mathrm{P}$. Also $\alpha$ - and $\beta$-Proteobacteria were grouped in direction of SW, which had narrowest $C$ : nutrient ratios.

Besides the determination of the community structure based on present proteins, we were able to detect extracellular litter degrading enzymes in the metaproteomics approach. The main functional groups were xylanases, pectinases, cellulases and proteases. Both fungi and bacteria contributed to the enzyme production (Supplement Table S2). Extracellular litter degrading enzymes were mainly of fungal origin; particularly Ascomycota contributed to the production in all litter types and at both sampling times (Supplement Table 2). Highest enzyme abundances (Supplement Table S2) and en- zyme activities (Fig. 1) were observed at the nutrient richest site $\mathrm{SW}$; lower abundances and activities were observed for $\mathrm{KL}$ and $\mathrm{OS}$, with widest $\mathrm{C}: \mathrm{P}$ and $\mathrm{C}: \mathrm{N}$ ratio respectively. This indicates a strong "site" i.e. litter stoichiometry, effect in the production of extracellular enzymes. Furthermore, an increase of total enzyme abundances was observed over time. As the abundances of extracellular enzymes were still low at the second sampling time, a further investigation of their phylogenetic origin was not possible because of generally low spectral counts. However, our results underpin that the applied method provides the possibility to investigate the link between microbial community structures and its decomposer functioning (Supplement Table 2).

\section{Discussion}

To answer our research questions, we elucidated which factors drove beech litter decomposition in terms of enzyme and microbial activities as well as microbial community structure. We studied beech litter decomposition with varying nutrient stoichiometry under controlled conditions in microcosms, and suspected that the collective activity of microbial communities is to some extent controlled by differing nutrient availability (Moorhead and Sinsabaugh, 2006). Elevated concentrations of $\mathrm{N}$ and $\mathrm{P}$ have been shown to accelerate leaf decomposition via enhanced microbial activity (Cassio and 

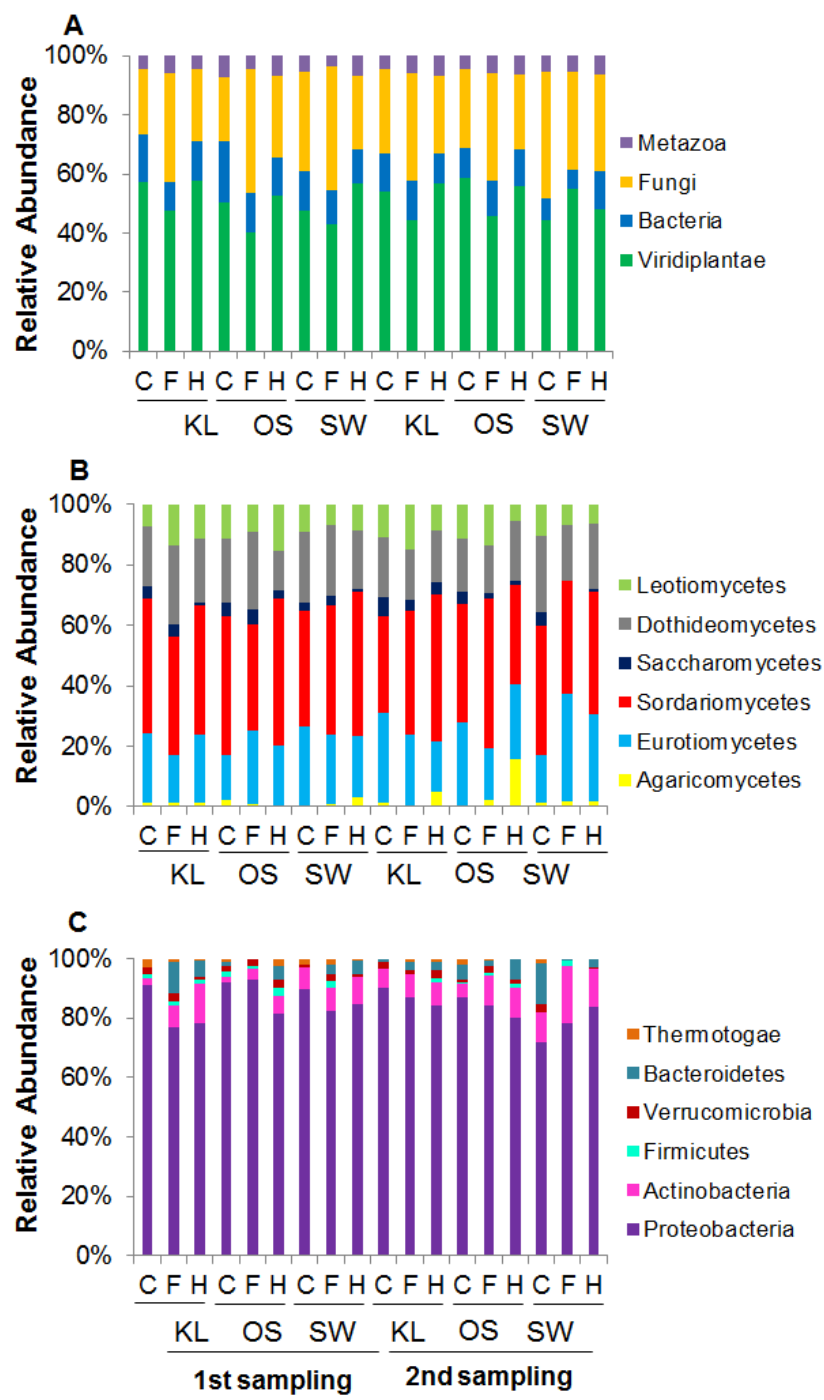

Fig. 2. Microbial community distribution, (A) general groups (B) fungal lineages of the Basidiomycota (Agaricomycetes), and the Ascomycota (Leotiomycetes, Dothideomycetes, Saccharomycetes and Eurotiomycetes) (C) bacterial lineages, the relative abundance of proteins observed at the different sampling time points including all treatments ("C" control; "F" freezing; " $\mathrm{H}$ " heat) and the different locations from where the leaf litter were derived ("KL" Klausenleopoldsdorf; "OS" Ossiach; "SW" Schottenwald).

Pascoal, 2004). In addition to allowing microbes to access energy and nutrients present in complex substrates, enzyme activities catalyse the initial, rate limiting step of decomposition and nutrient mineralization (Allison and Vitousek, 2005). Because enzyme production is $\mathrm{N}$ and energy insensitive, microbes should only produce enzymes at the expense of growth and metabolism if available nutrients are scarce. Enzyme production can be an inducible response to the presence of complex substrates (Allison and Vitousek, 2005).

As expected, beech litter stoichiometry affected potential enzyme activities as generally higher enzyme activities were
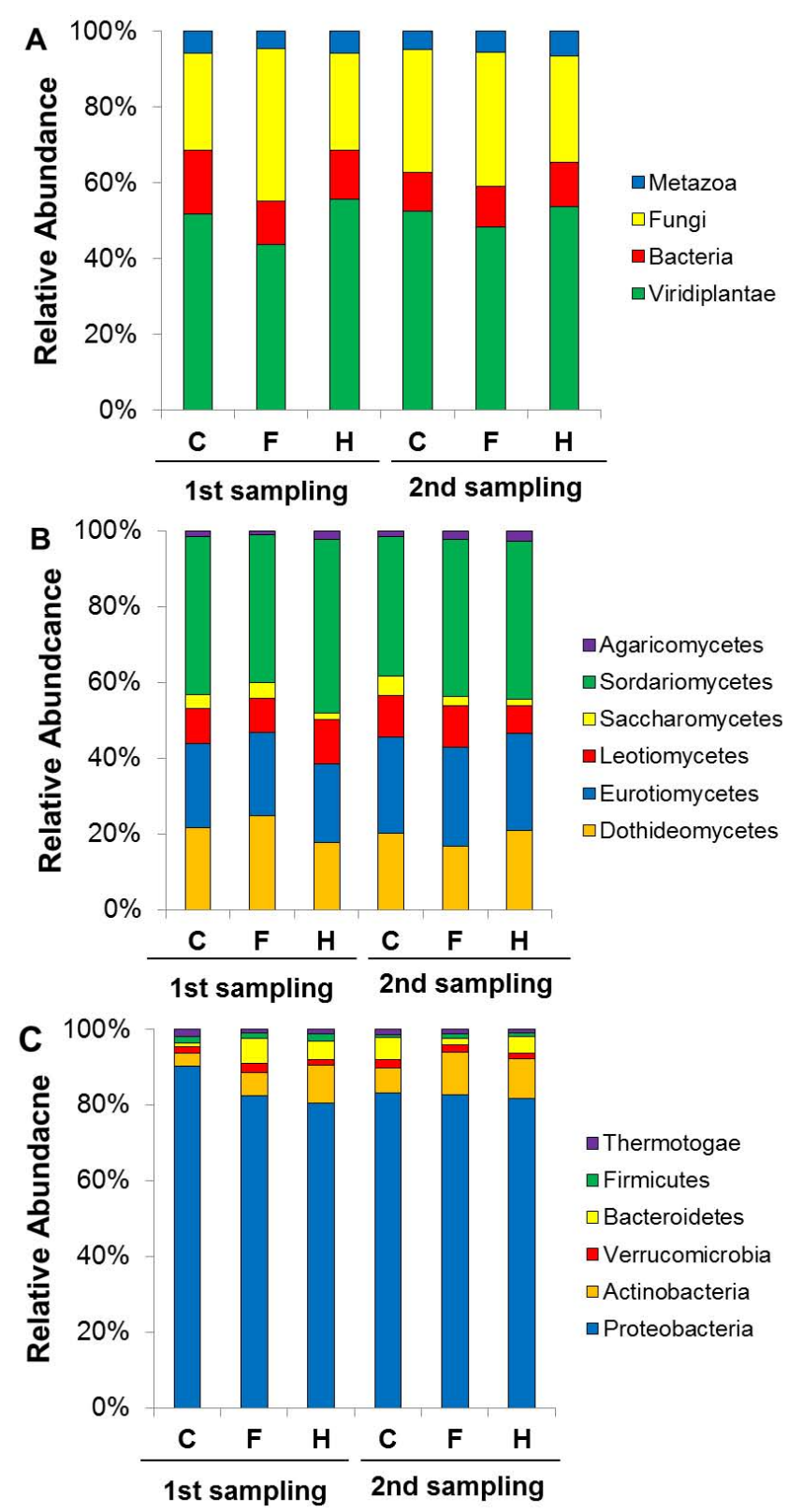

Fig. 3. Microbial community distribution comparing treatments (by grouping sites), (A) general groups (B) fungal lineages of the Basidiomycota (Agaricomycetes), and the Ascomycota (Leothiomycetes, Dothideomycetes, Saccharomycetes) (C) bacterial lineages. The relative abundance of proteins observed at the different smapling time points comparing all treatments (" $C$ " control; " $F$ " freezing; " $H$ " heat). The values displayed are the mean of the three different sites to obtain replicates for analysis of treatments. 1st sampling was two weeks after treatments and 2nd sampling was three months after treatments.

found in beech litter with narrow $\mathrm{C}$ : nutrient stoichiometry. During the early stages of decomposition, microbial N limitation can occur due to high microbial $\mathrm{N}$ demand (Moorhead and Sinsabaugh, 2006). Thus, $\mathrm{N}$ is proposed to accelerate 

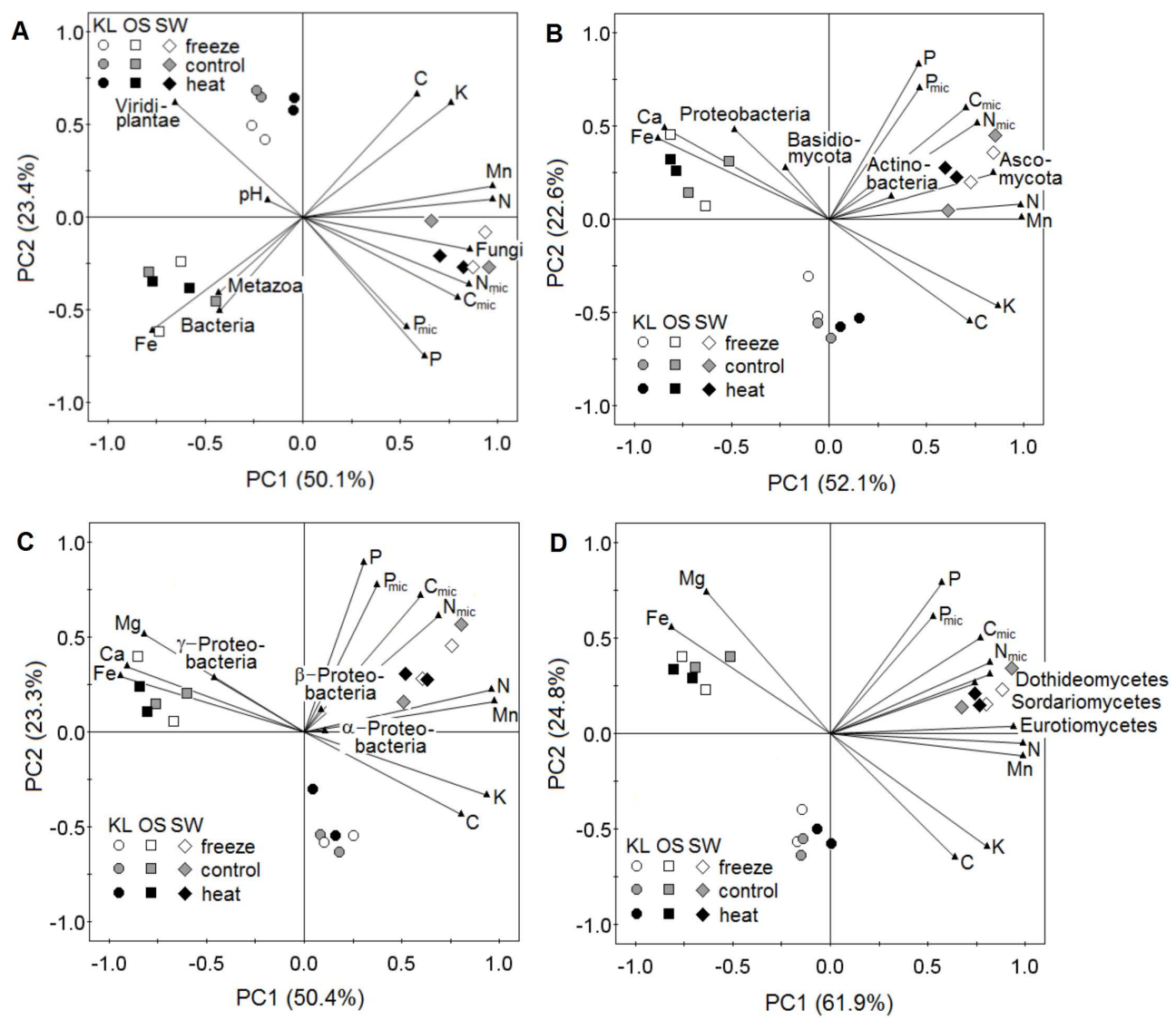

Fig. 4. Principal component analysis of microbial community structure: (A) two components of general domains Bacteria, Fungi, Viridplantae and Metazoa, (B) two components of general bacterial and fungal phyla, (C) two components of the phylum of Proteobacteria, and (D) PCA of the phylum of Ascomycota, and the individual elements involved magnesium ( $\mathrm{Mg})$, calcium (Ca), iron (Fe), manganese (Mn), potassium $(\mathrm{K})$, and phosphorus $(\mathrm{P})$, carbon $(\mathrm{C})$, nitrogen $(\mathrm{N})$, and microbial biomass $\mathrm{C}\left(\mathrm{C}_{\mathrm{mic}}\right)$, microbial biomass $\mathrm{N}\left(\mathrm{N}_{\text {mic }}\right)$ and microbial biomass $\mathrm{P}\left(\mathrm{P}_{\text {mic }}\right)$. The number in brackets indicates the percentage of variance which is explained by the principal component. The different locations where the litter derived from were indicated as follows: circles - Klausenleopoldsdorf (KL), squares - Ossiach (OS) and diamonds - Schottenwald (SW). Varying shades were selected for the treatments, white for freezing treatment, grey for control and black for heat treatment.

decomposition during the early stages, while it might have an inhibiting effect during the late stages (Gallo et al., 2004). Although beech litter can be completely decomposed within one year in the field, e.g. at site SW (Zechmeister-Boltenstern et al., 2002), we assume that within the six months of our artificial decomposition study the litter was still in a relatively early stage of decomposition. This is indicated by the low abundance of extracellular enzymes and the dominance of pectin and xylan degrading enzymes. These enzymes are produced in the first stage of decomposition when easily accessible material is still present in the litter material. Litter $\mathrm{C}: \mathrm{N}$ ratios declined over time, while extracellular enzyme activities increased, especially those which were targeting high-molecular weight organic $\mathrm{C}$ compounds, e.g. cellulase, chitinase, peroxidase and phenoloxidase. A release of $\mathrm{C}$ substrates together with microbial growth reinforces microbial N demand (Moorhead and Sinsabaugh, 2006) and can aggravate microbial $\mathrm{N}$ limitation. Phosphorous $(\mathrm{P})$ availability may also have an impact on the decomposition process as it may limit the production of cellulolytic enzymes (Sterner and Elser, 2002).

In the present study, leaf litter P concentration was not related with phosphatase activity but positively related to all other enzyme activities under stable conditions. In addition, our results showed a weak impact of $\mathrm{P}$ on $\mathrm{N}$ acquiring enzyme activities (protease activity) under stable conditions and after heat treatment, while Olander and Vitousek (2000) found that $\mathrm{P}$ addition had no impact on $\mathrm{N}$ acquiring enzymes. The relationships in our investigation could result from increased investment of abundant $\mathrm{N}$ into extracellular enzymes mining for $\mathrm{P}$ to maintain stoichiometric $\mathrm{N}$ : P balance of the microbes. As $\mathrm{P}$ was not significantly related to protease activity after freezing, this indicates that freezing had a stronger disturbance effect during the decomposition process than heat. Temperature perturbations decreased potential hydrolytic enzyme activity dramatically. 
The reductions in microbial activity after temperature stress could be explained by selective modification of microbial community functions (Dell et al., 2012) and may reflect differences in protein turnover (Duke and Doehlert, 1996). Peroxidase and Phenoloxidase are lignin degrading enzymes and are supposed to be down-regulated under high $\mathrm{N}$ deposition, which results in reduced lignin decomposition of substrates with low lignin concentrations by inhibiting synthesis of ligninolytic enzymes (Carreiro et al., 2000) or by reacting with breakdown products of lignin degradation to form other recalcitrant compounds (Hobbie, 2008). While narrow $\mathrm{C}: \mathrm{N}$ ratios did not result in inhibited activity of ligninolytic enzymes in the present study, still the nutritional status was more pronounced for these enzyme activities than for cellulase and protease activity where temperature perturbations had a stronger impact.

The present study shows that resource stoichiometry influences decomposer communities (Fig. 2), supporting the findings of Cleveland and Liptzin (2007) that showed that $\mathrm{C}$ and nutrients were utilized in specific stoichiometric ratios to maintain balanced growth conditions.

A metaproteomic approach was applied in order to determine microbial community structure and to link it with microbial function. Metaproteomics has the potential to link processes/functions to microbes on the basis of the active building blocks in the system, namely the proteins, as was shown recently for litter-inhabiting microbial communities collected in the field (Schneider et al., 2012) and soil samples (Keiblinger et al., 2012). However, data on microbial abundance obtained in the present study should be considered with respect to the fact that the respective metagenome data were not available for the generated mass spectra and those protein database searches, though protein assignment is based on general databases. The obtained results as well as data interpretation might be improved with data from metagenome analyses from the respective litter samples. However, increasing numbers of pyro-sequencing studies have already improved the database situation, and additional database information will be available in the future by a continued sequencing effort (Siggins et al., 2012).

The study of mixed microbial communities within their changing environment is key to the investigation of the diverse roles played by microorganisms. As metaproteomics focuses on the translated proteins and the metabolites resulting from microbial activity occurring under certain environmental conditions, it can be used to identify the metabolic pathways and cellular processes at work within an ecosystem. This simplified controlled experimental setup together with a newly developed metaproteomics approach allowed us for the first time to dissect the interactions between resource stoichiometry, enzyme activity and microbial community on the protein level. To follow the decomposer succession from the same starting conditions, the litter was sterilized and reinoculated to destroy the native microbial community and to follow the development of distinct microbial communi- ties and the related process dynamics based on differences in litter quality/stoichiometry, excluding site-specific differences in microbial inoculum, soils, temperature and humidity. The use of one source of litter inoculum (instead of three) also enabled studying the development of microbial communities adapted to litters of different elemental composition starting from one homogenous "metacommunity", therefore circumventing any possible differences in composition and metabolic capabilities of microbial inoculum on litter decomposition processes. Our results are therefore not valid for natural ecosystems; in fact the scope of our study was to investigate basic relationships between resource quality (elemental stoichiometry, $\mathrm{C}$ chemistry) temperature perturbations, microbial community and the related enzymatic activities. In order to find the main microbial drivers of decomposition, the microbial decomposer community and its respective function was investigated in detail.

Fungi have been recognized as dominant players in microbial decomposition of leaf litter in streams and in terrestrial ecosystems, whereas bacteria are thought to increase their importance only after leaf material has been partially broken down (Gulis and Suberkropp, 2003; Schneider et al., 2012). In general, fungi produce a wider range of extracellular enzymes than bacteria (de Boer et al., 2005; Romani et al., 2006), and terrestrial fungi, in particular Basidiomycetes, can degrade even highly recalcitrant detritus such as wood (de Boer et al., 2005; Romani et al., 2006).

In all our samples, fungi were the dominant microbial decomposers, followed by bacteria. This observation corroborates the finding that fungi are the main degraders and are specialized in highly complex C compounds in rivers (Gulis and Suberkropp, 2003). Higher fungal abundance and activity may also favour bacterial abundance through the availability of intermediate products from enzymatic degradation via fungal derived enzymes. In depth analysis of the fungal community showed that it was dominated by Ascomycota, which were favoured in sites with narrow $\mathrm{C}$ : nutrient ratios, as were their subphyla (Dothideomycetes, Eurotiomycetes and Sordariomycetes); Ascomycota also dominated decomposer activity, i.e. the production of extracellular enzymes. Viridiplantae loss (which we used as a surrogate for litter decomposition), and higher fungal abundance were both positively related to nutrient contents $(\mathrm{N}, \mathrm{P})$. Bacterial abundance was only affected to a minor extent.

Nutrient availability to microbes may limit the production of cellulolytic and other extracellular enzymes. In addition, the nutrient composition of litter is selective for certain microbial populations that are the producers of extracellular enzymes. During the decomposition of plant material, $\mathrm{C}: \mathrm{N}$ ratios of the substrate will decline as $\mathrm{C}$ is released through respiration by the decomposing organisms. When substrate $\mathrm{C}: \mathrm{N}$ ratio is so narrow that $\mathrm{C}$ becomes limiting, microorganisms are forced to primarily use N-rich substrates as a $\mathrm{C}$ source (e.g. proteins, peptides, amino acids). Intracellular enzymes remove excess $\mathrm{N}$ and subsequently exude mineral 
$\mathrm{N}$ into the environment. This release through the activity of decomposer microorganisms has been regarded as the major rate limiting step in the $\mathrm{N}$ cycle (Schimel and Bennett, 2004).

It has been proposed that the initial phase of decomposition is usually dominated by pioneer species like Zygomycota or so called "sugar fungi" (Osono, 2007), which metabolize easily available $\mathrm{C}$ and are fast growers (Torres et al., 2005) that start colonizing the leaf surface. The succession then continues with Ascomycota who have only limited ability to attack lignin (Torres et al., 2005). Although investigating the early stages of decomposition in this study, the metaproteomics approach revealed only a minor impact of Zygomycota (Mucuromycotina) and a strong dominance of Ascomycota in the fungal community. Later in the decomposition process, Basidiomycota increased in their abundance (mean NSAF value of Basidiomycota increased by 2.4-fold at the second sampling compared to the first sampling), presumably due to their ability to degrade the recalcitrant litter material (Torres et al., 2005) and to obtain nutrients by decomposing dead organic matter (Osono, 2007). As decomposition proceeds, fast growing opportunistic microbes $(Z y$ gomycota and Ascomycota) are usually succeeded by Basidiomycota, which are slower growing decomposers specialized in degradation of more recalcitrant substrate (Osono, 2007).

In the present study, for the litter from the SW site with narrow $\mathrm{C}$ : nutrient ratios, a larger decrease in remaining plant litter material - Viridiplantae abundance - was determined, which implies accelerated decomposition, as the non-degraded plant proteins can be considered as markers for the amount of remaining litter material (Schneider et al., 2012). Stress of certain intensity can alter the microbial community at any stage of decomposition (Fierer et al., 2010). In our study, microbial community analysis using the metaproteomic approach revealed that freezing treatment had a stronger effect on the microbial community structure than heat treatment. Microbes can survive and remain active after temperature stress (heat, freezing) by physiological acclimation (Schimel et al., 2007). This might be the reason that fungi were favoured after freezing treatment while the reduction in bacterial abundance was a transient effect. Abundance of Viridiplantae declined after freezing, which indicates that freezing accelerated decomposition in the short term. For instance, freezing involves physical processes of cell lysis and disruption by the formation of ice crystals, which render substrates available for decomposers processes (Schimel et al., 2007) that do not occur in the heat treatment. Microbial community structures changed less in the heat treatment, especially the abundance of fungi showed minor effects (Fig. 3). In field experiments of soil warming, heat effects on microbial community structure were difficult to detect although microbial function (i.e. respiration rates) was largely altered (Schindlbacher et al., 2011). Although the microbial community might respond only minor to temperature stress, the acclimation and stress repair costs can have strong effects on the allocation of $\mathrm{C}$ and nutrients to growth, respiration and extracellular enzyme production. This can be deduced from the greatly altered activities of most investigated enzymes (notably cellulases, chitinases, phosphatases and proteases) in our study. As well as an increase in accumulated respiration of treated leaf litter in relation to control samples, especially freezing revealed significant increases in accumulated respiration at the second sampling. Linking taxon identity to function is a major challenge in microbial ecology (Nannipieri et al., 2003). Although metaproteomics is still in its infancy, this post-genomic approach overcomes some of the methodological limitations of genetic as well as cultivationbased methods (Schneider et al., 2010; Strickland and Rousk, 2010). The study of Romani and co-workers (2006) deals with enzymatic activities and the impact of fungi and bacteria and their contributions to leaf litter decomposition based on DNA (DGGE), while the present study links microbial activity and microbial phylogeny at the extracellular enzyme level. Generally, extracellular enzymes derived mainly from fungi. The Ascomycota within the phylum of fungi were most abundant and active. Interestingly, this is consistent with the findings of (Baldrian et al., 2011) who investigated the litter layer of a Norway spruce forest soil using a metatranscriptome approach but not addressing specific enzymes, and Schneider et al. (2012) who investigated litter samples taken directly from the environment using a metaproteomics approach.

In conclusion we can answer our research questions $(Q)$ as follows: with respect to $Q 1$, we state that resource stoichiometry had a strong influence on microbial community structure (metaproteomic results), whereas community functions (enzyme activities) were generally affected by the interaction of at least two factors. Extreme temperatures $(Q 2)$ strongly reduced all enzyme activities. It is possible $(Q 3)$ to at least qualitatively link microbial community structure using metaproteomics to the decomposition process. In addition, the contribution of major phylogenetic groups can be linked to decomposer function.

Although the overriding factor influencing decomposing community is stoichiometry, $\mathrm{C}$ quantity in relation to $\mathrm{N}$ is not the only determinant of decay rate that should be considered. Enzyme activity measurements permit the functional response of the microbial community to litter quality and other environmental factors which were followed. Altered enzyme responses signal to temperature perturbation on the short term, and atmospheric $\mathrm{N}$ deposition on the long term may be affecting the global $\mathrm{C}$ cycle by influencing the activities of microbes and their $\mathrm{C}$ acquiring enzymes, especially the unique ligninolytic enzymes produced (Carreiro et al., 2000). Stronger effects on activities after heat stress were observed, although strongest effect on the microbial abundance was after frost stress, indicating that perturbations may affect the system in different ways and possible feedback mechanisms. Climate change through increased nutrient inputs via $\mathrm{N}$ deposition tends to shift enzyme activity away 
from polyphenol oxidation and towards polysaccharide hydrolysis and phosphatase activity (Sinsabaugh et al., 2002). It has been mentioned that phenoloxidase is also suppressed under anaerobic conditions, by this end warming or changes in precipitation can affect the decomposition of recalcitrant leaf litter material (Fenner and Freeman, 2011). The main advantage of the present study was the possibility to relate enzymes to their microbial origin using metaproteomics.

\section{Supplementary material related to this article is available online at: http://www.biogeosciences.net/9/ 4537/2012/bg-9-4537-2012-supplement.zip.}

Acknowledgements. The Austrian Academy of Sciences (ÖAW) granted Katharina Keiblinger with a DOC-fFORTE fellowship and the European Science Foundation (ESF) with an exchange grant entitled "Climatic Change - Manipulation Experiments in Terrestrial Ecosystems". This research was performed within the National Research Network MICDIF (S100) of the Austrian Science Fund FWF (Project numbers S10001,2,3,4,6,7-B17). Thanks to Brigitte Schraufstädter, Alfred Fürst and Barbara Kitzler for lab assistance. Special thanks to the anonymous reviewers who have donated their time and expertise to greatly improve the manuscript.

Edited by: G. Herndl

\section{References}

Allison, S. D. and Vitousek, P. M.: Responses of extracellular enzymes to simple and complex nutrient inputs, Soil Biol. Biochem., 37, 937-944, doi:10.1016/j.soilbio.2004.09.014, 2005.

Allison, S., Gartner, T., Holand, K., Weintraub, M., and Sinsabaugh, R.: Soil enzymes: linking proteomics and ecological process, Environ. Microbiol., 3rd Edition, 704-711, 2006.

Baldrian, P., Kolarik, M., Stursova, M., Kopecky, J., Valaskova, V., Vetrovsky, T., Zifcakova, L., Snajdr, J., Ridl, J., Vlcek, C., and Voriskova, J.: Active and total microbial communities in forest soil are largely different and highly stratified during decomposition, ISME J., 6, 248-258, doi:10.1038/ismej.2011.95, 2012.

Carreiro, M. M., Sinsabaugh, R. L., Repert, D. A., and Parkhurst, D. F.: Microbial enzyme shifts explain litter decay responses to simulated nitrogen deposition, Ecology, 81, 2359-2365, doi: $10.2307 / 177459,2000$.

Cassio, F. and Pascoal, C.: Contribution of fungi and bacteria to leaf litter decomposition in a polluted river, Appl. Environ. Microb., 70, 5266-5273, doi:10.1128/Aem.70.9.5266-5273.2004, 2004.

Christensen, J. H. and Christensen, O. B.: A summary of the PRUDENCE model projections of changes in European climate by the end of this century, Climatic Change, 81, 7-30, doi:10.1007/s10584-006-9210-7, 2007.

Cleveland, C. C. and Liptzin, D.: C: N : P stoichiometry in soil: is there a "Redfield ratio" for the microbial biomass?, Biogeochemistry, 85, 235-252, doi:10.1007/s10533-007-9132-0, 2007.
Couteaux, M. M., Bottner, P., and Berg, B.: Litter Decomposition, Climate and Litter Quality, Trends Ecol. Evol., 10, 63-66, 1995.

Craig, R. and Beavis, R. C.: TANDEM: matching proteins with tandem mass spectra, Bioinformatics, 20, 1466-1467, doi:10.1093/bioinformatics/bth092, 2004.

de Boer, W., Folman, L. B., Summerbell, R. C., and Boddy, L.: Living in a fungal world: impact of fungi on soil bacterial niche development, Fems Microbiol. Rev., 29, 795-811, doi:10.1016/j.femsre.2004.11.005, 2005.

Dell, E. A., Carley, D. S., Rufty, T., and Shi, W.: Heat stress and $\mathrm{N}$ fertilization affect soil microbial and enzyme activities in the creeping bentgrass (Agrostis Stolonifera L.) rhizosphere, Appl. Soil Ecol., 56, 19-26, doi:10.1016/j.apsoil.2012.02.002, 2012.

Doyle, A., Weintraub, M. N., and Schimel, J. P.: Persulfate digestion and simultaneous colorimetric analysis of carbon and nitrogen in soil extracts, Soil Sci. Soc. Am. J., 68, 669-676, 2004.

Duke, E. R. and Doehlert, D. C.: Effects of heat stress on enzyme activities and transcript levels in developing maize kernels grown in culture, Environ. Exp. Bot., 36, 199-208, 1996.

Fenner, N. and Freeman, C.: Drought-induced carbon loss in peatlands, Nat. Geosci., 4, 895-900, doi:10.1038/Ngeo1323, 2011.

Fierer, N., Nemergut, D., Knight, R., and Craine, J. M.: Changes through time: integrating microorganisms into the study of succession, Res. Microbiol., 161, 635-642, doi:10.1016/J.resmic.2010.06.002, 2010.

Fischer, E. M. and Schar, C.: Consistent geographical patterns of changes in high-impact European heatwaves, Nat. Geosci., 3, 398-403, doi10.1038/Ngeo866, 2010.

Florens, L., Carozza, M. J., Swanson, S. K., Fournier, M., Coleman, M. K., Workman, J. L., and Washburn, M. P.: Analyzing chromatin remodeling complexes using shotgun proteomics and normalized spectral abundance factors, Methods, 40, 303-311, doi:10.1016/j.ymeth.2006.07.028, 2006.

Gallo, M., Amonette, R., Lauber, C., Sinsabaugh, R. L., and Zak, D. R.: Microbial community structure and oxidative enzyme activity in nitrogen-amended north temperate forest soils, Microb. Ecol., 48, 218-229, doi:10.1007/s00248-003-9001-x, 2004.

Gulis, V. and Suberkropp, K.: Effect of inorganic nutrients on relative contributions of fungi and bacteria to carbon flow from submerged decomposing leaf litter, Microb. Ecol., 45, 11-19, doi:10.1007/s00248-002-1032-1, 2003.

Henschler, G.: Analysen im biologischen Material Vol. 2, VCH Verlagsgesellschaft mbH, Weinheim, Germany, 1988.

Hobbie, S. E.: Nitrogen effects on decomposition: A five-year experiment in eight temperate sites, Ecology, 89, 2633-2644, doi:10.1890/07-1119.1, 2008.

Hungate, B. A., Dukes, J. S., Shaw, M. R., Luo, Y. Q., and Field, C. B.: Nitrogen and climate change, Science, 302, 1512-1513, doi:10.1126/science.1091390, 2003.

Kaiser, C., Koranda, M., Kitzler, B., Fuchslueger, L., Schnecker, J., Schweiger, P., Rasche, F., Zechmeister-Boltenstern, S., Sessitsch, A., and Richter, A.: Belowground carbon allocation by trees drives seasonal patterns of extracellular enzyme activities by altering microbial community composition in a beech forest soil, New Phytol., 187, 843-858, doi:10.1111/j.14698137.2010.03321.x, 2010.

Keiblinger, K. M., Hall, E. K., Wanek, W., Szukics, U., Hammerle, I., Ellersdorfer, G., Bock, S., Strauss, J., Sterflinger, K., Richter, A., and Zechmeister-Boltenstern, S.: The effect 
of resource quantity and resource stoichiometry on microbial carbon-use-efficiency, Fems Microbiol. Ecol., 73, 430-440, doi:10.1111/j.1574-6941.2010.00912.x, 2010.

Keiblinger, K. M., Wilhartitz, I. C., Schneider, T., Roschitzki, B., Schmid, E., Eberl, L., Riedel, K., and Zechmeister-Boltenstern, S.: Soil metaproteomics - Comparative evaluation of protein extraction protocols, Soil Biol. Biochem., 54, 14-24, doi:10.1016/j.soilbio.2012.05.014, 2012.

Keller, A., Nesvizhskii, A. I., Kolker, E., and Aebersold, R.: Empirical statistical model to estimate the accuracy of peptide identifications made by MS/MS and database search, Anal. Chem., 74, 5383-5392, doi:10.1021/ac025747h, 2002.

Kitzler, B., Zechmeister-Boltenstern, S., Holtermann, C., Skiba, U., and Butterbach-Bahl, K.: Nitrogen oxides emission from two beech forests subjected to different nitrogen loads, Biogeosciences, 3, 293-310, doi:10.5194/bg-3-293-2006, 2006.

Laemmli, U. K.: Cleavage of structural proteins during the assembly of the head of bacteriophage T4, Nature, 227, 680-685, 1970.

Leitner, S., Wanek, W., Wild, B., Haemmerle, I., Kohl, L., Keiblinger, K. M., Zechmeister-Boltenstern, S., and Richter, A.: Influence of litter chemistry and stoichiometry on glucan depolymerization during decomposition of beech (Fagus sylvatica L.) litter, Soil Biol. Biochem., 50, 174-187, doi:10.1016/j.soilbio.2012.03.012, 2012.

Luo, Y. Q., Zhang, D. Q., Hui, D. F., and Zhou, G. Y.: Rates of litter decomposition in terrestrial ecosystems: global patterns and controlling factors, J. Plant Ecol.-UK, 1, 85-93, doi:10.1093/jpe/rtn002, 2008.

Moorhead, D. L. and Sinsabaugh, R. L.: A theoretical model of litter decay and microbial interaction, Ecol. Monogr., 76, 151-174, 2006.

Mooshammer, M., Wanek, W., Schnecker, J., Wild, B., Leitner, S., Hofhansl, F., Blöchl, A., Hämmerle, I., Frank, A. H., Fuchslueger, L., Keiblinger, K. M., Zechmeister-Boltenstern, S., and Richter, A.: Stoichiometric controls of nitrogen and phosphorus cycling in decomposing beech leaf litter, Ecology, 93, 770-782, doi:10.1890/11-0721.1, 2012.

Nannipieri, P.: Role of Stabilised Enzymes in Microbial Ecology and Enzyme Extraction from Soil with Potential Applications in Soil,in: Nucleic Acids and Proteins in Soil, edited by: Nannipieri, P. and Smalla, K., Soil Biology, Springer Berlin Heidelberg, 7594, 2006.

Nannipieri, P., Ascher, J., Ceccherini, M. T., Landi, L., Pietramellara, G., and Renella, G.: Microbial diversity and soil functions, Eur. J. Soil. Sci., 54, 655-670, doi:10.1046/j.13510754.2003.0556.x, 2003.

Nesvizhskii, A. I., Keller, A., Kolker, E., and Aebersold, R.: A statistical model for identifying proteins by tandem mass spectrometry, Anal. Chem., 75, 4646-4658, doi:10.1021/Ac0341261, 2003.

Ogunseitan, O.: Soil Proteomics: Extraction and Analysis of Proteins from Soils, in: Nucleic Acids and Proteins in Soil,edited by: Nannipieri, P. and Smalla, K., Soil Biology, Springer Berlin Heidelberg, 95-115, 2006.

Olander, L. P. and Vitousek, P. M.: Regulation of soil phosphatase and chitinase activity by $\mathrm{N}$ and $\mathrm{P}$ availability, Biogeochemistry, 49, 175-190, 2000.

Osono, T.: Ecology of ligninolytic fungi associated with leaf litter decomposition, Ecol. Res., 22, 955-974, doi:10.1007/s11284- 007-0390-z, 2007.

Prescott, C. E.: Litter decomposition: what controls it and how can we alter it to sequester more carbon in forest soils?, Biogeochemistry, 101, 133-149, doi:10.1007/s10533-010-9439-0, 2010.

Romani, A. M., Fischer, H., Mille-Lindblom, C., and Tranvik, L. J.: Interactions of bacteria and fungi on decomposing litter: Differential extracellular enzyme activities, Ecology, 87, 2559-2569, 2006.

Schimel, J. P. and Bennett, J.: Nitrogen mineralization: Challenges of a changing paradigm, Ecology, 85, 591-602, 2004.

Schimel, J., Balser, T. C., and Wallenstein, M.: Microbial stressresponse physiology and its implications for ecosystem function, Ecology, 88, 1386-1394, 2007.

Schindlbacher, A., Rodler, A., Kuffner, M., Kitzler, B., Sessitsch, A., and Zechmeister-Boltenstern, S.: Experimental warming effects on the microbial community of a temperate mountain forest soil, Soil Biol. Biochem., 43, 1417-1425, doi:10.1016/j.soilbio.2011.03.005, 2011.

Schinner, F., Öhlinger, R., Kandeler, E., and Margesin, R.: Methods in Soil Biology, 426pp., Springer-Verlag, Berlin, 1996.

Schneider, T., Gerrits, B., Gassmann, R., Schmid, E., Gessner, M. O., Richter, A., Battin, T., Eberl, L., and Riedel, K.: Proteome analysis of fungal and bacterial involvement in leaf litter decomposition, Proteomics, 10, 1819-1830, doi:10.1002/pmic.200900691, 2010.

Schneider, T., Schmid, E., de Castro, J. V., Cardinale, M., Eberl, L., Grube, M., Berg, G., and Riedel, K.: Structure and function of the symbiosis partners of the lung lichen (Lobaria pulmonaria L. Hoffm.) analyzed by: metaproteomics, Proteomics, 11, 27522756, doi:10.1002/pmic.201000679, 2011.

Schneider, T., Keiblinger, K. M., Schmid, E., Sterflinger-Gleixner, K., Ellersdorfer, G., Roschitzki, B., Richter, A., Eberl, L., Zechmeister-Boltenstern, S., and Riedel, K.: Who is who in litter decomposition? Metaproteomics reveals major microbial players and their biogeochemical functions, ISME J., 6, 1749-1762, doi:10.1038/ismej.2012.11, 2012.

Shevchenko, A., Wilm, M., Vorm, O., and Mann, M.: Mass spectrometric sequencing of proteins silver-stained polyacrylamide gels, Anal. Chem., 68, 850-858, 1996.

Siggins, A., Gunnigle, E., and Abram, F.: Exploring mixed microbial community functioning: recent advances in metaproteomics, Fems Microbiol. Ecol., 80, 265-280, doi:10.1111/j.15746941.2011.01284.x, 2012.

Sinsabaugh, R. L., Carreiro, M. M., and Repert, D. A.: Allocation of extracellular enzymatic activity in relation to litter composition, $\mathrm{N}$ deposition, and mass loss, Biogeochemistry, 60, 1-24, 2002.

Sinsabaugh, R. L., Lauber, C. L., Weintraub, M. N., Ahmed, B., Allison, S. D., Crenshaw, C., Contosta, A. R., Cusack, D., Frey, S., Gallo, M. E., Gartner, T. B., Hobbie, S. E., Holland, K., Keeler, B. L., Powers, J. S., Stursova, M., Takacs-Vesbach, C., Waldrop, M. P., Wallenstein, M. D., Zak, D. R., and Zeglin, L. H.: Stoichiometry of soil enzyme activity at global scale, Ecol. Lett., 11, 1252-1264, doi:10.1111/j.1461-0248.2008.01245.x, 2008.

Sterner, R. W. and Elser, J. J.: Ecological stoichiometry: The biology of elements from molecules to the biosphere, Princeton University Press, Princeton, 2002.

Strickland, M. S. and Rousk, J.: Considering fungal:bacterial dominance in soils - Methods, controls, and ecosystem implications, Soil Biol. Biochem., 42, 1385-1395, 
doi:10.1016/j.soilbio.2010.05.007, 2010.

Torres, P. A., Abril, A. B., and Bucher, E. H.: Microbial succession in litter decomposition in the semi-arid Chaco woodland, Soil Biol. Biochem., 37, 49-54, doi:10.1016/j.soilbio.2004.04.042, 2005.

Tringe, S. G., von Mering, C., Kobayashi, A., Salamov, A. A., Chen, K., Chang, H. W., Podar, M., Short, J. M., Mathur, E. J., Detter, J. C., Bork, P., Hugenholtz, P., and Rubin, E. M.: Comparative metagenomics of microbial communities, Science, 308, 554557, doi:10.1126/science.1107851, 2005.

Vizcaino, J. A., Cote, R., Reisinger, F., Foster, J. M., Mueller, M., Rameseder, J., Hermjakob, H., and Martens, L.: A guide to the proteomics identifications database proteomics data repository, Proteomics, 9, 4276-4283, doi:10.1002/pmic.200900402, 2009.
Wanek, W., Mooshammer, M., Blochl, A., Hanreich, A., Keiblinger, K., Zechmeister-Boltenstern, S., and Richter, A.: Determination of gross rates of amino acid production and immobilization in decomposing leaf litter by a novel $(15) \mathrm{N}$ isotope pool dilution technique $(42,1293,2010)$, Soil Biol. Biochem., 43, 221-221, doi:10.1016/j.soilbio.2010.09.031, 2011.

Zechmeister-Boltenstern, S., Hahn, M., Meger, S., and Jandl, R.: Nitrous oxide emissions and nitrate leaching in relation to microbial biomass dynamics in a beech forest soil, Soil Biol. Biochem., 34, 823-832, 2002.

Zybailov, B., Mosley, A. L., Sardiu, M. E., Coleman, M. K., Florens, L., and Washburn, M. P.: Statistical analysis of membrane proteome expression changes in Saccharomyces cerevisiae, J. Proteome Res., 5, 2339-2347, doi:10.1021/Pr060161n, 2006. 